\title{
SECRETION OF CIRCULATING ANTIBODIES INTO SEMINAL PLASMA IN MEN
}

\author{
T. N. S. UDUPA, USHA M. JOSHI, SHANTA S. RAO \\ AND D. S. PARDANANI* \\ Institute for Research in Reproduction (ICMR), Parel, Bombay 12, and \\ *Department of Surgery, Seth G.S. Medical College, Bombay 12, India
}

(Received 10th September 1973)

Infertility in certain males has been attributed to the presence of circulating autoantibodies to spermatozoa (Wilson, 1954; Rao \& Sadri, 1959; Hanafiah, Epstein \& Sobrero, 1972). Doubts have been expressed, however, about the clinical significance of these antibodies because they have been observed to be present in some fertile men (Fjallbrant, 1967; S. S. Rao, T. N. S. Udupa \& S. S. Dikshit, unpublished observations). Various immunological methods, such as the sperm agglutination technique of Kibrick (Kibrick, Belding \& Merril, 1952), microagglutination of spermatozoa (Franklin \& Dukes, 1964), passive haemagglutination test (Rao \& Sadri, 1959; Rangnekar \& Rao, 1972), have been employed for detecting the presence of anti-sperm antibodies. It is possible that the tests used do not detect clinically signficant levels of antibodies in fertile men possessing such antibodies. Another possibility is that the spermspecific antibodies, though present in the blood, might not find access to the reproductive tract in order to become physiologically effective. The present work was undertaken to examine whether or not, in every individual, the antibodies in circulation find access to the reproductive tract. Tetanus toxoid was used as a model antigen to test this possibility.

Fourteen human subjects were immunized with $1 \mathrm{ml}$ tetanus toxoid. Two injections, each of $10 \mathrm{Lf}$ in $1 \mathrm{ml}$, were given intramuscularly at an interval of 1 month. (The Lf, or flocculating unit, is defined as that amount of toxin, or toxoid, which flocculates most rapidly with 1 unit of antitoxin in a series of mixtures containing constant amounts of toxin and varying amounts of antitoxin: Zinsser, 1968.) Blood and semen samples were collected 10 days after the second injection. Anti-tetanus antibodies in the serum and the globulin fraction of the seminal plasma were estimated using a passive haemagglutination test. The secretory status of eight of the subjects was assessed according to the method described by Mollison (1961)

The results are shown in Table 1. Significant levels of anti-tetanus antibodies were encountered in the seminal plasma of twelve of the fourteen subjects. The remaining two did not have detectable amounts of antibodies in the seminal plasma in spite of high titres being present in the blood serum. There was, however, no correlation between the levels of antibodies in the serum and in the seminal plasma. 
Table 1. Levels of tetanus antitoxin in the blood and seminal plasma of fourteen men and the relation to secretory status

\begin{tabular}{l|c|c|c}
\hline Subject & $\begin{array}{c}\text { Tetanus antitoxin } \\
\text { in serum }(i . u . / m l)\end{array}$ & $\begin{array}{c}\text { Tetanus antitoxin } \\
\text { in seminal plasma } \\
(i . u . / m l)\end{array}$ & $\begin{array}{c}\text { Secretory } \\
\text { status }\end{array}$ \\
\hline G.C.P. & 1.25 & 0.625 & N.D. \\
V.J.A. & 0.625 & Nil & N.D. \\
I.K. & 10 & 0.625 & N.D. \\
K.B. & 7.5 & 0.078 & N.D. \\
A.G.K. & N.D. & 0.125 & N.D. \\
L.S. & 4 & 0.015 & + \\
G.S.G. & 5 & 0.5 & + \\
R.B.K. & 1.25 & 1.25 & + \\
B.G.S. & N.D. & 0.625 & + \\
V.M.S. & 0.325 & 0.15 & + \\
S.D. & 1.25 & 0.45 & + \\
B.D.T. & 1.25 & Nil & + \\
R.J.K. & 5 & 1.25 & + \\
G.H.C. & 20 & 0.625 & N.D. \\
\hline
\end{tabular}

N.D. $=$ Not done.

All the eight subjects whose secretory status was studied were found to be secretors. One of these did not show the presence of anti-tetanus antibodies in his seminal plasma. Thus, the secretion of antibodies into seminal plasma does not seem to be related to the secretory status.

Specific antibodies in the seminal plasma have in the past been demonstrated by Wilson (1954) and Rao \& Sadri (1959). The results reported in this communication indicate that, in some men, circulating antibodies do not find access to the seminal plasma.

\section{REFERENGES}

FJallbrant, B. O. (1967) Fertility in a man autoimmunized to spermatozoa. F. Reprod. Fert. 14, 143.

FrankLin, R. R. \& Dukes, C. D. (1964) Antispermatozoal antibody and unexplained infertility. Am. F. Obstet. Gynec. 89, 6.

Hanafiah, M. J., Epstein, J. A. \& Sobrero, A. J. (1972) Sperm agglutinating antibodies in 236 infertile couples. Fert. Steril. 23, 493.

Kibrick, S., Belding, D. L. \& Merril, B. (1952) Methods for the detection of antibodies against mammalian spermatozoa. II. A gelatin agglutination test. Fert. Steril. 1, 338.

Mollison, P. L. (Ed.) (1961) Blood Transfusion in Clinical Medicine, 3rd edn, p. 383. Blackwell Scientific Publications, Oxford.

Rangnekar, K. N. \& Rao, S. S. (1972) Passive haemagglutination test to detect and assay circulating antibodies to seminal antigens. Indian $\mathcal{F}$. med. Res. 60, 704.

RAO, S. S. \& SADRI, K. K. (1959) Immunological studies with human semen and cervical mucus. Proc. 6th Int. Conf. plann. Parent., New Delhi, 6, 313.

Wirson, L. (1954) Spermagglutinins in human semen and blood. Proc. Soc. exp. Biol. Med. 85, 652.

Zinsser, H. (1968) Microbiology, 14th edn, p. 316. Eds. D. T. Smith, N. F. Canant and P. Willett. Appleton-Century-Crofts, New York. 